\title{
Optimization of CNC CO2 Laser Cutting Process Parameters on Acrylic Cutting Using Taguchi Grey Relational Analysis and Response Surface Methodology
}

\section{Eldinar Oktatian}

Sebelas Maret University

Cucuk Nur Rosyidi ( $\square$ cucuknur@staff.uns.ac.id )

Sebelas Maret University

Eko Pujiyanto

Sebelas Maret University

\section{Research Article}

Keywords: CO2 laser cutting, craylic, Taguchi, Grey Relational Analysis, Response Surface Methodology (RSM)

Posted Date: November 15th, 2021

DOI: https://doi.org/10.21203/rs.3.rs-1048691/v1

License: (c) (1) This work is licensed under a Creative Commons Attribution 4.0 International License.

Read Full License 


\title{
OPTIMIZATION OF CNC CO 2 LASER CUTTING PROCESS PARAMETERS ON ACRYLIC CUTTING USING TAGUCHI GREY RELATIONAL ANALYSIS AND RESPONSE SURFACE METHODOLOGY
}

\author{
Eldinar Mohammad Oktatian, Cucuk Nur Rosyidi, and Eko Pujiyanto \\ Departement of Industrial Engineering, Faculty of Engineering, Universitas Sebelas Maret, \\ Jl. Ir. Sutami no. 36 A, Kentingan, Surakarta, Central Java, Indonesia \\ Corresponding author: eldinarokta@gmail.com, cucuknur@staff.uns.ac.id, \\ ekopujiyanto@staff.uns.ac.id
}

\begin{abstract}
Polymethylmethacrylate (acrylic) has some important characteristics such as light weight, impact-resistant, and high durability. In a manufacturing industry, acrylic has been widely used as the basic material for billboard products, decorative lights, canopies, and room decorations. This research aims at determining the optimal process parameters of the laser cutting process. The experiment was conducted using multi-response Taguchi method involving four responses, namely processing time, dimensional accuracy, surface roughness, and carbon emissions. The Taguchi method is used to determine the Signal to Noise (SNR) for each response. The Grey Relational Analysis (GRA) method is performed by calculating the normalized weight of SNR for each response to determine the optimal setting level of each factor applied in the experiment. The Response Surface Methodology (RSM) was applied to determine the mathematical model based on the results of the experiment to allow the multiobjective optimization and determine the exact value of optimal process parameters which simultaneously compromise all the responses. Based on the results of the experiment, the optimal process parameters are $65 \%$ of the laser power, $4 \mathrm{~mm} / \mathrm{s}$ of the cutting speed, and $4 \mathrm{~mm}$ of nozzle distance. Whereas from the results multi-objective optimization, the optimal process parameters are $75 \%$ of laser power, $5.9 \mathrm{~mm} / \mathrm{s}$ of cutting speed, and $3 \mathrm{~mm}$ of nozzle distance.
\end{abstract}

Keyword: $\mathrm{CO}_{2}$ laser cutting, craylic, Taguchi, Grey Relational Analysis, Response Surface Methodology (RSM)

\section{Introduction}

Manufacturing process is a serial process to produce physical or chemical changes in a material with the aim at adding some values to the material (Groover, 2012). It is estimated that about $60 \%$ to $80 \%$ of the entire process of components was done by machining process (Widarto, 2008). $\mathrm{CNC} \mathrm{CO}_{2}$ laser cutting machines are commonly used to cut materials with intricate patterns from hard sheet materials with a short processing time (Rakasita R., 2016). This machine allows us to produce a variety of products from thick plate materials. The advantage of laser cutting is that very fine welds, even thinner than the thickness of the material, may be formed (Naresh and Khatak, 2021). The other advantages of laser cutting include suitable for delicate and brittle materials, the final surface quality can be achieved in one step, and no further finishing operations are needed to smooth and clean the surface, very high cutting speed, and ease of automation (Moradi et al., 2021). 
Currently, plastic is widely used as the basic material of various industrial products, since this material is much easier to process and turn into more complex products. The plastic is a synthetic polymer, made of chemicals which cannot be decomposed naturally in the environment (Bambang A., 2015). One type of plastic polymers is Polymethylmethacrylate (PMMA) which has some interesting properties such as impact resistant, lighter, durable, and not easy to break. PMMA has been widely used as the basic material for billboard products, decorative lights, home canopies, and room decorations. It also widely used for many kinds of toys, boxes, device housings and electronics, cement for fixing hip and joint prostheses, and aquatic products such as domestic and commercial aquariums (Eltawahni et al., 2019).

There are several problems when manufacturing mass products from the acrylic material such as how to increase the efficiency, reducing the defects, improving the surface quality, and reduce the carbon emissions. Processing time is one of the important factors in determining the production efficiency. The processing time is directly related to the cutting speed of the workpiece (Kim, 2007). The higher the cutting speed, the lower the processing time. The quality problems due to the defects and surface conditions can be reduced by increasing the dimensional accuracy of the process and reducing the surface roughness. Either the dimensional accuracy and surface roughness has been considered as the responses in the research of Mathivanan (2010). Besides those economic and technical measures, carbon emissions are unavoidable during the laser cutting process and have a detrimental effect on human health and environments (Lopez, 2017). Comparing to other manufacturing processes, CO2 laser cutting needs a higher energy (Naresh and Khatak, 2021). It means that the laser cutting process emitted higher carbon emissions than the other manufacturing processes. energy means. Due to the global concerns of sustainability issues in manufacturing, the carbon emissions are among the variables that should be considered in the manufacturing process (ElHofy, 2013).

There are many researches have been conducted in determining the optimal process parameters of $\mathrm{CNC} \mathrm{CO}_{2}$ laser cutting machines. Kellens et al. (2014) conducted a research to efficiently using energy in laser cutting machining processes. The purpose of the study was to determine the amount of electrical energy consumed during the machining process and measure the amount of carbon emissions during the process with different laser power. The results of the study were used to determine the remedial steps of the laser cutting process. Acherjee (2014) conducted a research to optimize the underwater Nd:YAG laser micro-channeling on PMMA using Grey Relational Analysis (GRA) method. Armansyah (2016) conducted research to optimize the PMMA cutting process parameters against surface roughness in laser cutting using response surface methodology (RSM). Chen et al. (2016) conducted research to optimize the surface quality of CO2 laser cutting process of PMMA microchannels using Taguchi method. Rakasita et al. (2016) conducted a study on the optimization of laser cutting machine parameters against surface roughness and cutting rate on SUS 316L materials using Taguchi GRA method with the aims at minimizing surface roughness and maximizing material removal rate (MRR). They considered several process parameters, namely the focal point, gas cutting pressure, and cutting speed with 3 levels at each parameter. Haddadi (2019) conducted a study on experimental and parametric evaluation of the cutting quality characteristic in CO2 Laser Cutting for polystyrene material. As with Kellens et al. (2014) the optimization was also done 
using Taguchi GRA method. Khamar and Prakash (2020) conducted research to investigate the dimension accuracy of the cutting process using CO2 Laser Cutting on Acrylic materials. The dimensions of the top and the bottom kerf specimen were used as the responses. The top kerf dimension is a measurement of the dimensions on the upper surface of the material facing the laser lens, while the bottom kerf dimension is the measurement of the dimensions on the lower surface of the material facing the machine's workspace. Ding, Wang, and Guo (2020) conducted research to optimize the fiber laser cutting based on generalized regression neural network and non-dominated sorting genetic algorithm.

Taguchi method is commonly used to efficiently and effectively improving a product quality. Among the advantages of the applications of Taguchi method is the adaptability of the method to simply and easily provide the information with a smaller number of experiments (Shaker et al, 2015). However, traditional Taguchi method can only be used to analyze a single response problem. Hence, in optimizing process parameters with multi responses, it requires other tools to perform the analysis. In today's high-tech processes, however, it is commonly found that a product has more than one quality response of main interest (Al-Refaie et al, 2010). In this study, we use Grey Relational Analysis (GRA) to solve multi-attribute decision making problems by converting all the value in each alternative into a single value, so as to reduce the original problem to a decision-making problem with a single attribute (Kuo et al, 2008). The optimal values resulting from the GRA method are in the forms of the levels at each factor specified at the beginning of the experiment. The Response Surface Methodology (RSM) method was used in this research to convert the results of the experiment into a mathematical model to determine the continuous value of each factor instead of the discrete one in the Taguchi method.

The aim of this research is to determine the optimal process parameters of PMMA cutting process in a CNC CO2 Laser Cutting machine using Taguchi method, GRA, and RSM. Three process parameters are used in this study include laser power, cutting speed, and nozzle distance. Four responses are considered in this research, namely processing time, dimensional accuracy, surface roughness, and carbon emission. The RSM is used to determine the mathematical model based on the results of experiment. The multi-objective optimization approach is used to determine the optimal process parameters. The rest of this paper is composed as follows. Section 2 explains the materials and methods. Section 3 provides the results and discussion, while the conclusions are drawn in the las section.

\section{Materials and Methods}

This research was conducted at Production System Laboratory, Industrial Engineering Department, Faculty of Engineering Universitas Sebelas Maret. Firstly, we define the responses, factors, and levels of this research. Three factors are considered in this research with three levels at each factor, namely laser power, cutting speed, and nozzle distance. Table 1 shows the factors and their respective levels. 
Table 1. Setting of level and factors for the experiment

\begin{tabular}{llccc}
\hline & & \multicolumn{3}{c}{ Level } \\
\cline { 3 - 5 } Factor & & 1 & 2 & 3 \\
\hline A & Laser Power & $55 \%$ & $65 \%$ & $75 \%$ \\
B & Cutting Speed & $4 \mathrm{~mm} / \mathrm{s}$ & $5 \mathrm{~mm} / \mathrm{s}$ & $6 \mathrm{~mm} / \mathrm{s}$ \\
C & Nozzle Distance & $3 \mathrm{~mm}$ & $4 \mathrm{~mm}$ & $5 \mathrm{~mm}$ \\
\hline
\end{tabular}

After defining the factors and their respective levels, we determine the appropriate orthogonal array to find the number of treatments in the experiment. Based on the number of factors and levels we decided to use $\mathrm{L}_{9}\left(3^{3}\right)$ of orthogonal array for this experiment as shown in Table 2.

Table 2. Orthogonal array $\mathrm{L}_{9}\left(3^{3}\right)$

\begin{tabular}{cccc}
\hline Treatment & Laser Power & Cutting Speed & $\begin{array}{c}\text { Nozzle } \\
\text { Distance }\end{array}$ \\
\hline 1 & $55 \%$ & $4 \mathrm{~mm} / \mathrm{s}$ & $3 \mathrm{~mm}$ \\
2 & $55 \%$ & $5 \mathrm{~mm} / \mathrm{s}$ & $4 \mathrm{~mm}$ \\
3 & $55 \%$ & $6 \mathrm{~mm} / \mathrm{s}$ & $5 \mathrm{~mm}$ \\
4 & $65 \%$ & $4 \mathrm{~mm} / \mathrm{s}$ & $4 \mathrm{~mm}$ \\
5 & $65 \%$ & $5 \mathrm{~mm} / \mathrm{s}$ & $5 \mathrm{~mm}$ \\
6 & $65 \%$ & $6 \mathrm{~mm} / \mathrm{s}$ & $3 \mathrm{~mm}$ \\
7 & $75 \%$ & $4 \mathrm{~mm} / \mathrm{s}$ & $5 \mathrm{~mm}$ \\
8 & $75 \%$ & $5 \mathrm{~mm} / \mathrm{s}$ & $3 \mathrm{~mm}$ \\
9 & $75 \%$ & $6 \mathrm{~mm} / \mathrm{s}$ & $4 \mathrm{~mm}$ \\
\hline
\end{tabular}

After texperiment, the specimens are then measured and tested according to each response. The processing time in this study was measured from the time of the machine start to cut specimens until finish the cutting process. The processing time is shown on the interface of the machine. The dimension measurements of the specimens were conducted using a vernier caliper (Tricle Brand) with the measurement accuracy of $0.05 \mathrm{~mm}$. The surface roughness is measured using a digital surface roughness tester of Mitutoyo SJ-201. The measurement device has the measurement ranges of $0.01 \mu \mathrm{m}-100 \mu \mathrm{m}$. The carbon emissions are measured using MQ-135 air quality sensors with MQ-135 sensitivity characteristics for gas measurements in $20{ }^{\circ} \mathrm{C}$ of temperature, $65 \%$ of humidity, $21 \%$ of $\mathrm{O}_{2}$ concentrations and resistor load (RL) of $20 \mathrm{k} \Omega$.

In this research, we used a CNC laser engraving machine of Indiao type Z1390 as shown in Figure 1. The material used in the experiments is PMMA with a thickness of $4 \mathrm{~mm}$ which will be cut in the dimensions of $50 \mathrm{~mm}$ x $50 \mathrm{~mm}$. In each treatment, a sample of three specimens is produced which will then be tested and measured according to each response. The response data are then analyzed using Taguchi GRA to determine the optimal setting of factors and levels, while the RSM was used to determine the mathematical model expressing the relationship between each response and the factors of experiment. The results of this model are then used as the input for multi-objective optimization approach. In this research, we use normalization approach which has been proved to be the most reliable approach to solve the multi-objective optimization problem (Marler and Arora, 2004). Microsoft Excel software is used to solve the multi-objective optimization model due to its easiness in developing the program with satisfactory results. 


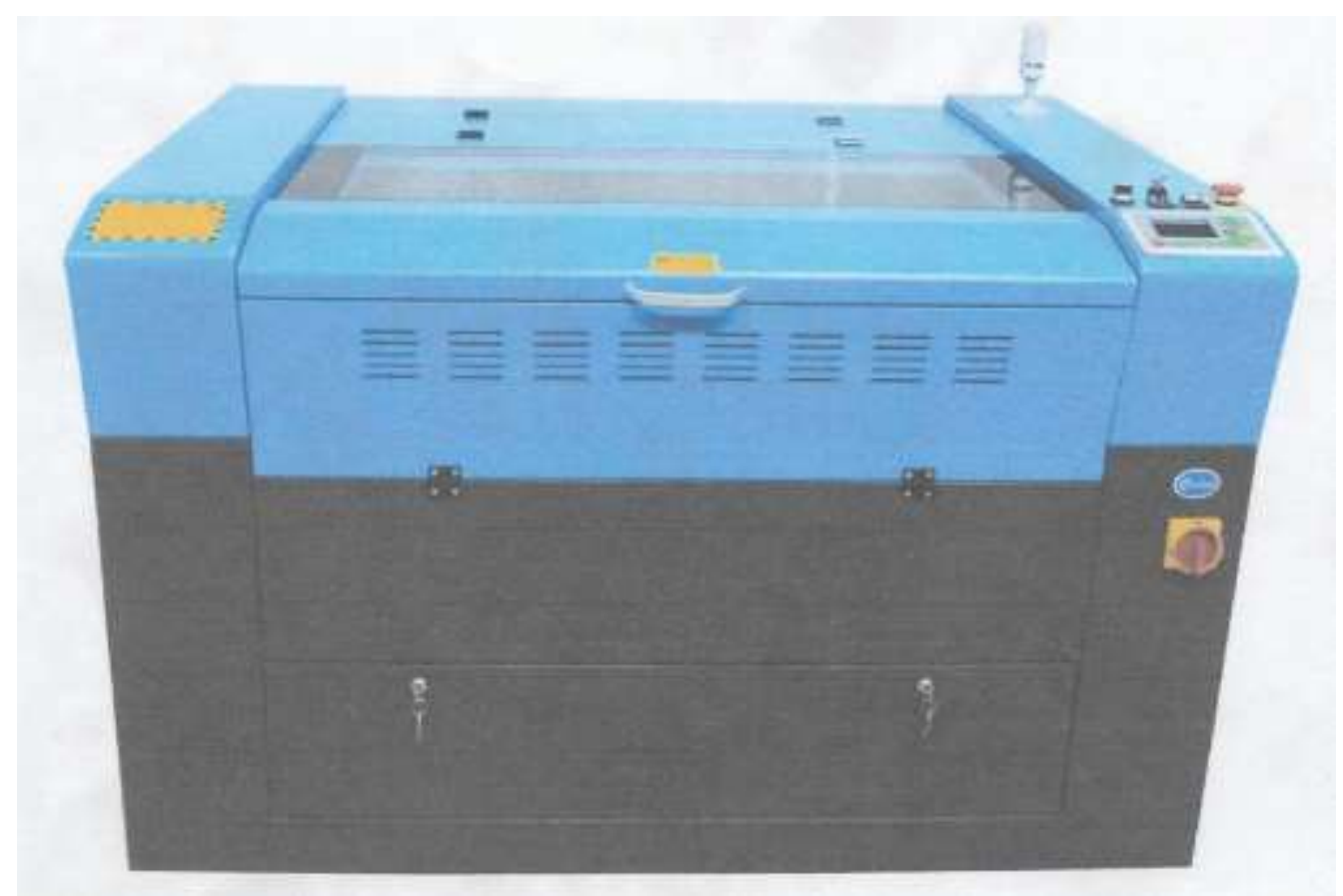

Figure 1. The machine used in the experiment

\section{Results and Discussions}

\subsection{Experimental Results}

The processing time, surface roughness, and carbon emission are responses that should be minimized, so those responses are included in smaller-the-better quality characteristics. While the dimensional accuracy should be maximized, so this response includes in larger-the-better quality characteristic. The results of each response and the respective Signal to Noise Ratio (SNR) for each treatment are shown in Table 3 and Table 4 respectively.

Table 3. Measurement results

\begin{tabular}{cccccccc}
\hline \multicolumn{7}{c}{ Factor and Level } & \multicolumn{4}{c}{ Response } \\
No & $\begin{array}{c}\text { Laser } \\
\text { Power }\end{array}$ & $\begin{array}{c}\text { Cutting } \\
\text { Speed }\end{array}$ & $\begin{array}{c}\text { Nozzle } \\
\text { Distance }\end{array}$ & $\begin{array}{c}\text { Processing } \\
\text { Time } \\
(\mathrm{s})\end{array}$ & $\begin{array}{c}\text { Dimensional } \\
\text { Accuracy } \\
(\%)\end{array}$ & $\begin{array}{c}\text { Surface } \\
\text { Roughness } \\
(\mathrm{Ra})\end{array}$ & $\begin{array}{c}\text { Carbon } \\
\text { Emission } \\
(\mathrm{ppm})\end{array}$ \\
\hline 1 & $55 \%$ & $4 \mathrm{~mm} / \mathrm{s}$ & $3 \mathrm{~mm}$ & 49 & $99.66 \%$ & 0.105 & 39.043 \\
2 & $55 \%$ & $5 \mathrm{~mm} / \mathrm{s}$ & $4 \mathrm{~mm}$ & 39 & $99.80 \%$ & 0.164 & 35.480 \\
3 & $55 \%$ & $6 \mathrm{~mm} / \mathrm{s}$ & $5 \mathrm{~mm}$ & 32 & $99.75 \%$ & 0.368 & 33.574 \\
4 & $65 \%$ & $4 \mathrm{~mm} / \mathrm{s}$ & $4 \mathrm{~mm}$ & 49 & $99.68 \%$ & 0.183 & 51.295 \\
5 & $65 \%$ & $5 \mathrm{~mm} / \mathrm{s}$ & $5 \mathrm{~mm}$ & 39 & $99.71 \%$ & 0.197 & 48.427 \\
6 & $65 \%$ & $6 \mathrm{~mm} / \mathrm{s}$ & $3 \mathrm{~mm}$ & 32 & $99.77 \%$ & 0.182 & 42.663 \\
7 & $75 \%$ & $4 \mathrm{~mm} / \mathrm{s}$ & $5 \mathrm{~mm}$ & 49 & $99.58 \%$ & 0.231 & 49.181 \\
8 & $75 \%$ & $5 \mathrm{~mm} / \mathrm{s}$ & $3 \mathrm{~mm}$ & 39 & $99.69 \%$ & 0.148 & 46.952 \\
9 & $75 \%$ & $6 \mathrm{~mm} / \mathrm{s}$ & $4 \mathrm{~mm}$ & 32 & $99.81 \%$ & 0.171 & 44.453 \\
\hline
\end{tabular}


Table 4. The SNR of each response

\begin{tabular}{cccccccc}
\hline \multicolumn{3}{c}{ Factor and Level } & \multicolumn{4}{c}{ Response } \\
No & $\begin{array}{c}\text { Laser } \\
\text { Power }\end{array}$ & $\begin{array}{c}\text { Cutting } \\
\text { Speed }\end{array}$ & $\begin{array}{c}\text { Nozzle } \\
\text { Distance }\end{array}$ & $\begin{array}{c}\text { Processing } \\
\text { Time } \\
(\mathrm{s})\end{array}$ & $\begin{array}{c}\text { Dimensional } \\
\text { Accuracy } \\
(\%)\end{array}$ & $\begin{array}{c}\text { Surface } \\
\text { Roughness } \\
(\mathrm{Ra})\end{array}$ & $\begin{array}{c}\text { Carbon } \\
\text { Emission } \\
(\mathrm{ppm})\end{array}$ \\
\hline 1 & $55 \%$ & $4 \mathrm{~mm} / \mathrm{s}$ & $3 \mathrm{~mm}$ & -33.8039 & -0.0295 & 19.2172 & -31.8683 \\
2 & $55 \%$ & $5 \mathrm{~mm} / \mathrm{s}$ & $4 \mathrm{~mm}$ & -31.8213 & -0.0174 & 15.3926 & -31.0524 \\
3 & $55 \%$ & $6 \mathrm{~mm} / \mathrm{s}$ & $5 \mathrm{~mm}$ & -30.1030 & -0.0217 & 8.6867 & -30.5813 \\
4 & $65 \%$ & $4 \mathrm{~mm} / \mathrm{s}$ & $4 \mathrm{~mm}$ & -33.8039 & -0.0280 & 14.6619 & -34.2099 \\
5 & $65 \%$ & $5 \mathrm{~mm} / \mathrm{s}$ & $5 \mathrm{~mm}$ & -31.8213 & -0.0256 & 13.8598 & -33.7183 \\
6 & $65 \%$ & $6 \mathrm{~mm} / \mathrm{s}$ & $3 \mathrm{~mm}$ & -30.1030 & -0.0203 & 14.0996 & -32.6287 \\
7 & $75 \%$ & $4 \mathrm{~mm} / \mathrm{s}$ & $5 \mathrm{~mm}$ & -33.8039 & -0.0363 & 12.7190 & -33.8400 \\
8 & $75 \%$ & $5 \mathrm{~mm} / \mathrm{s}$ & $3 \mathrm{~mm}$ & -31.8213 & -0.0266 & 16.4907 & -33.4391 \\
9 & $75 \%$ & $6 \mathrm{~mm} / \mathrm{s}$ & $4 \mathrm{~mm}$ & -30.1030 & -0.0164 & 14.9296 & -32.9596 \\
\hline
\end{tabular}

Figures 2-5 show the plot of SNR against each factor and level. From Figure 2, we can see that the laser power and nozzle distance have no effect on the processing time. While for the cutting speed, the higher the cutting speed, the lower processing time as expected. Hence, the optimal level of this factor for processing time response is Level 3. Figure 3 shows that the laser power factor affects the dimension accuracy. From the figure, it was found that the optimal setting for the dimension accuracy is Level 1 for laser power, Level 3 for the cutting speed, and Level 2 for the nozzle distance. From Figure 4, we can see that the optimal setting for laser power, cutting speed, and nozzle distance is at Level 3, Level 1, and Level 1 respectively. Finally, Figure 5 shows that the optimal setting to minimize the carbon emissions for laser power factor, cutting speed and nozzle distance are at Level 1, Level 3, and Level 1 respectively.

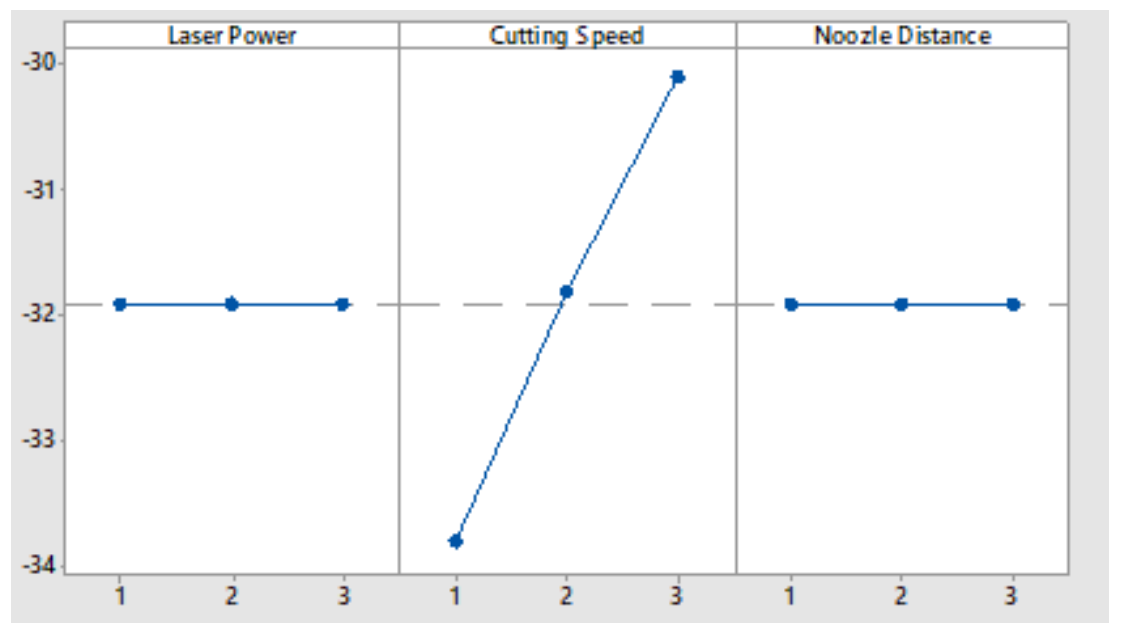

Figure 2. SNR plot for processing time 


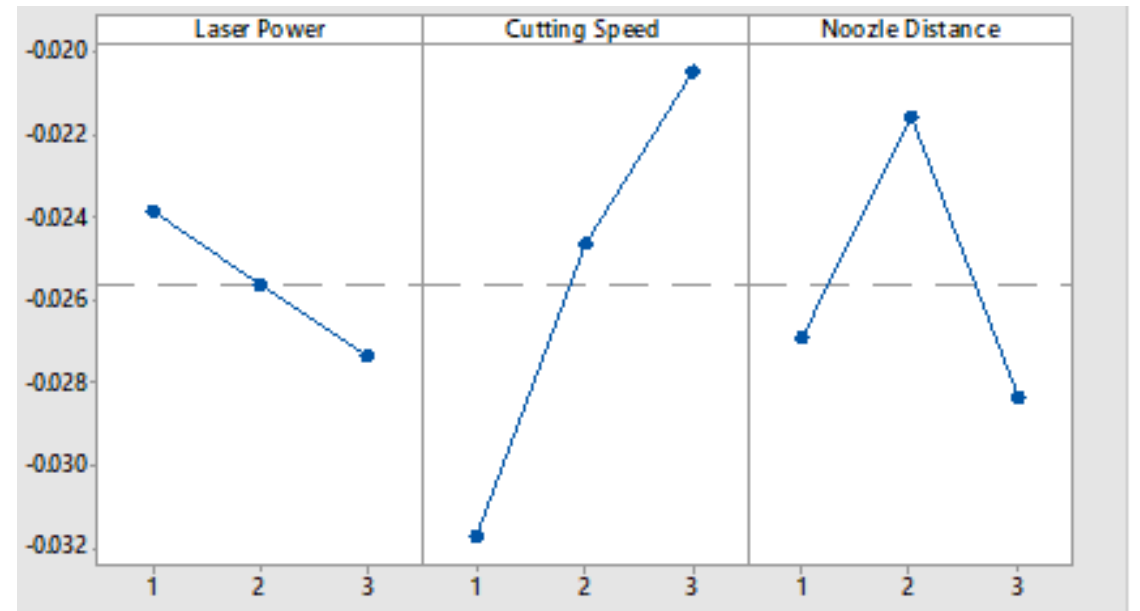

Figure 3. SNR Plot for dimensional accuracy

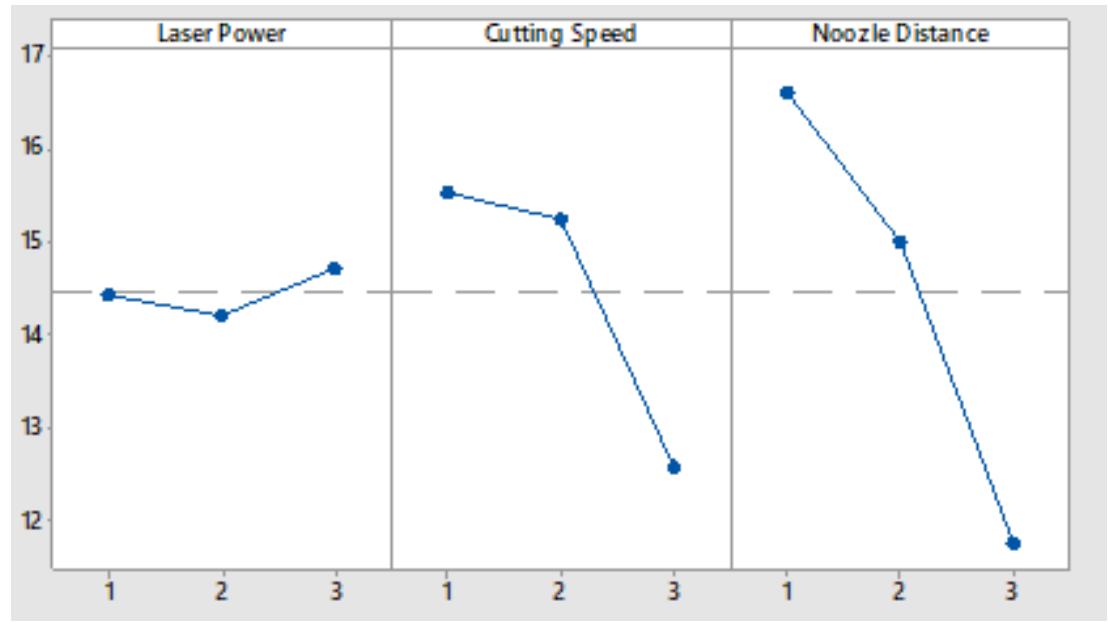

Figure 4. SNR plot for surface roughness

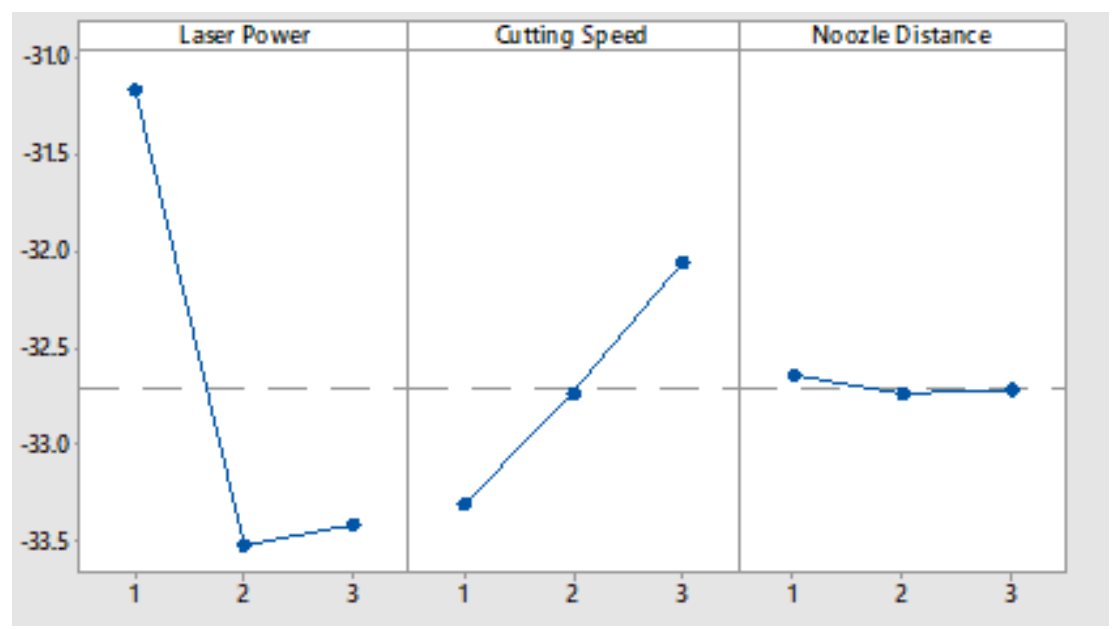

Figure 5. SNR plot for carbon emissions

ANOVA analysis was conducted to determine the significance effect of each factor to each response. Tables 5-8 show the results of ANOVA. From Table 5, the cutting speed becomes the only factor that significantly affect the processing time. Table 6 shows that cutting speed and nozzle distance are significantly affect the dimensional accuracy. From Table 7, the factors 
that significantly affect the surface roughness are cutting speed and nozzle distance While from Table 8 , the factors that significantly affect the carbon emissions are laser power and cutting speed.

Table 5. ANOVA of processing time

\begin{tabular}{lcrrrc}
\hline \multicolumn{7}{c}{ ANOVA for Response Processing Time } & & \\
\hline Source & df & \multicolumn{1}{c}{ Adj SS } & Adj MS & F-Value & P-Value \\
\hline Laser Power & 2 & 0.00 & 0.00 & 0 & 1.000 \\
Cutting Speed & 2 & 1314.00 & 657.00 & $\sim$ & $0.000^{*}$ \\
Nozzle Distance & 2 & 0.00 & 0.00 & 0 & 1.000 \\
Error & 20 & 0.00 & 0.00 & & \\
Lack-of-Fit & 2 & 0.00 & 0.00 & 0 & 1.000 \\
Pure Error & 18 & 0.00 & 0.00 & & \\
Total & 26 & 1314.00 & & & \\
\hline
\end{tabular}

Tabel 6. ANOVA of dimensional analysis

\begin{tabular}{lcccrc}
\hline \multicolumn{7}{c}{ ANOVA for Response Dimensional Accuracy } \\
\hline Source & df & Adj SS & Adj MS & F-Value & P-Value \\
\hline Laser Power & 2 & 0.000001 & 0.000000 & 1.92 & 0.173 \\
Cutting Speed & 2 & 0.000008 & 0.000004 & 19.84 & $0.000^{*}$ \\
Nozzle Distance & 2 & 0.000003 & 0.000002 & 7.75 & $0.003^{*}$ \\
Error & 20 & 0.000004 & 0.000000 & & \\
Lack-of-Fit & 2 & 0.000000 & 0.000000 & 0.06 & 0.944 \\
Pure Error & 18 & 0.000004 & 0.000000 & & \\
Total & 26 & 0.000015 & & &
\end{tabular}

Table 7. ANOVA of surface roughness

\begin{tabular}{lccccc}
\hline \multicolumn{7}{c}{ ANOVA for Response Surface Roughness } \\
\hline Source & df & Adj SS & Adj MS & F-Value & P-Value \\
\hline Laser Power & 2 & 0.004479 & 0.002240 & 0.61 & 0.552 \\
Cutting Speed & 2 & 0.028418 & 0.014209 & 3.88 & $0.038^{*}$ \\
Nozzle Distance & 2 & 0.071276 & 0.035638 & 9.74 & $0.001^{*}$ \\
Error & 20 & 0.073189 & 0.003659 & & \\
Lack-of-Fit & 2 & 0.025551 & 0.012776 & 4.83 & $0.021^{*}$ \\
Pure Error & 18 & 0.047638 & 0.002647 & & \\
Total & 26 & 0.177362 & & & \\
\hline
\end{tabular}

Table 8. ANOVA of carbon emission

\begin{tabular}{lcrrrr}
\hline \multicolumn{7}{c}{ ANOVA for Response Carbon Emission } \\
\hline Source & df & Adj SS & Adj MS & F-Value & P-Value \\
\hline Laser Power & 2 & 744.86 & 372.430 & 30.73 & $0.000^{*}$ \\
Cutting Speed & 2 & 177.64 & 88.820 & 7.33 & $0.004^{*}$ \\
$\quad$ Nozzle Distance & 2 & 4.32 & 2.160 & 0.18 & 0.838 \\
Error & 20 & 242.43 & 12.122 & & \\
$\quad$ Lack-of-Fit & 2 & 13.79 & 6.895 & 0.54 & 0.590 \\
$\quad$ Pure Error & 18 & 228.63 & 12.702 & & \\
Total & 26 & 1169.24 & & & \\
\hline
\end{tabular}




\subsection{The Optimal Setting}

The GRA is used to determine simultaneously the optimal setting of the process parameters for all responses. GRA has several following steps (Kuo et al, 2008):

Step 1: Normalize the SNR based on the nature of quality characteristics using the following equations:

$$
\begin{array}{ll}
\text { Larger The Better: } & X_{i}^{*}(k)=\frac{X_{0}(k)-\operatorname{Min} X_{0}(k)}{\operatorname{Max} X_{0}(k)-\operatorname{Min} X_{0}(k)} \\
\text { Smaller The Better: } & X_{i}^{*}(k)=\frac{\operatorname{Max} X_{0}(k)-X_{0}(k)}{\operatorname{Max} X_{0}(k)-\operatorname{Min} X_{0}(k)}
\end{array}
$$

Step 2 Calculate the deviation using Equation (3).

$$
\Delta(k)=\mid X_{i} \text { maks }-X_{i}^{*}(k) \mid
$$

Step 3 Determine the Grey Relational Coefficient (GRC) using the Equation (4).

$$
\mathrm{\gamma}\left(X_{0}(k), X_{i}(k)\right)=\frac{\Delta_{\min }+\zeta \Delta_{\max }}{\Delta_{(k)}+\zeta \Delta_{\max }}
$$

Tables 9-12 show the results of GRA by following the above steps for each response used in this research.

\begin{tabular}{|c|c|c|c|c|c|c|}
\hline \multicolumn{7}{|c|}{ Gray Relational Value of Dimensional Accuracy Response } \\
\hline \multirow{2}{*}{ No } & \multicolumn{3}{|c|}{ Combination of Parameter } & \multirow{2}{*}{ Normalization } & \multirow{2}{*}{ Deviation } & \multirow{2}{*}{ GRC } \\
\hline & Laser Power & Cutting Speed & Nozzle Distance & & & \\
\hline 1 & $55 \%$ & $4 \mathrm{~mm} / \mathrm{s}$ & $3 \mathrm{~mm}$ & 0.3417 & 0.6583 & 0.4317 \\
\hline 2 & $55 \%$ & $5 \mathrm{~mm} / \mathrm{s}$ & $4 \mathrm{~mm}$ & 0.9510 & 0.0490 & 0.9107 \\
\hline 3 & $55 \%$ & $6 \mathrm{~mm} / \mathrm{s}$ & $5 \mathrm{~mm}$ & 0.7319 & 0.2681 & 0.6509 \\
\hline 4 & $65 \%$ & $4 \mathrm{~mm} / \mathrm{s}$ & $4 \mathrm{~mm}$ & 0.4147 & 0.5853 & 0.4607 \\
\hline 5 & $65 \%$ & $5 \mathrm{~mm} / \mathrm{s}$ & $5 \mathrm{~mm}$ & 0.5368 & 0.4632 & 0.5191 \\
\hline 6 & $65 \%$ & $6 \mathrm{~mm} / \mathrm{s}$ & $3 \mathrm{~mm}$ & 0.8051 & 0.1949 & 0.7195 \\
\hline 7 & $75 \%$ & $4 \mathrm{~mm} / \mathrm{s}$ & $5 \mathrm{~mm}$ & 0.0000 & 1.0000 & 0.3333 \\
\hline 8 & $75 \%$ & $5 \mathrm{~mm} / \mathrm{s}$ & $3 \mathrm{~mm}$ & 0.4880 & 0.5120 & 0.4941 \\
\hline 9 & $75 \%$ & $6 \mathrm{~mm} / \mathrm{s}$ & $4 \mathrm{~mm}$ & 1.0000 & 0.0000 & 1.0000 \\
\hline
\end{tabular}

Table 9. Grey Relational Value of processing time

\begin{tabular}{ccccccc}
\hline \multirow{2}{*}{ No Combination of Parameter } & & Normalization & Deviation & GRC \\
\cline { 2 - 4 } & $\begin{array}{c}\text { Laser } \\
\text { Power }\end{array}$ & $\begin{array}{c}\text { Cutting } \\
\text { Speed }\end{array}$ & $\begin{array}{c}\text { Nozzle } \\
\text { Distance }\end{array}$ & & & \\
\hline 1 & $55 \%$ & $4 \mathrm{~mm} / \mathrm{s}$ & $3 \mathrm{~mm}$ & 1.0000 & 0.0000 & 1.0000 \\
2 & $55 \%$ & $5 \mathrm{~mm} / \mathrm{s}$ & $4 \mathrm{~mm}$ & 0.4643 & 0.5357 & 0.4828 \\
3 & $55 \%$ & $6 \mathrm{~mm} / \mathrm{s}$ & $5 \mathrm{~mm}$ & 0.0000 & 1.0000 & 0.3333 \\
4 & $65 \%$ & $4 \mathrm{~mm} / \mathrm{s}$ & $4 \mathrm{~mm}$ & 1.0000 & 0.0000 & 1.0000 \\
5 & $65 \%$ & $5 \mathrm{~mm} / \mathrm{s}$ & $5 \mathrm{~mm}$ & 0.4643 & 0.5357 & 0.4828 \\
6 & $65 \%$ & $6 \mathrm{~mm} / \mathrm{s}$ & $3 \mathrm{~mm}$ & 0.0000 & 1.0000 & 0.3333 \\
7 & $75 \%$ & $4 \mathrm{~mm} / \mathrm{s}$ & $5 \mathrm{~mm}$ & 1.0000 & 0.0000 & 1.0000 \\
8 & $75 \%$ & $5 \mathrm{~mm} / \mathrm{s}$ & $3 \mathrm{~mm}$ & 0.4643 & 0.5357 & 0.4828 \\
9 & $75 \%$ & $6 \mathrm{~mm} / \mathrm{s}$ & $4 \mathrm{~mm}$ & 0.0000 & 1.0000 & 0.3333 \\
\hline
\end{tabular}

Table 10. Grey Relational Value of dimensional accuracy 
Table 11 Grey Relational Value of surface roughness

\begin{tabular}{ccccccc}
\hline \multicolumn{7}{c}{ Gray Relational Value of Surface Roughness Response } \\
\cline { 1 - 4 } No & \multicolumn{7}{c}{ Combination of Parameter } & Normalization & Deviation & GRC \\
\cline { 2 - 5 } & Laser Power & Cutting Speed & Nozzle Distance & & & \\
\hline 1 & $55 \%$ & $4 \mathrm{~mm} / \mathrm{s}$ & $3 \mathrm{~mm}$ & 0.0000 & 1.0000 & 0.3333 \\
2 & $55 \%$ & $5 \mathrm{~mm} / \mathrm{s}$ & $4 \mathrm{~mm}$ & 0.3632 & 0.6368 & 0.4398 \\
3 & $55 \%$ & $6 \mathrm{~mm} / \mathrm{s}$ & $5 \mathrm{~mm}$ & 1.0000 & 0.0000 & 1.0000 \\
4 & $65 \%$ & $4 \mathrm{~mm} / \mathrm{s}$ & $4 \mathrm{~mm}$ & 0.4326 & 0.5674 & 0.4684 \\
5 & $65 \%$ & $5 \mathrm{~mm} / \mathrm{s}$ & $5 \mathrm{~mm}$ & 0.5088 & 0.4912 & 0.5044 \\
6 & $65 \%$ & $6 \mathrm{~mm} / \mathrm{s}$ & $3 \mathrm{~mm}$ & 0.4860 & 0.5140 & 0.4931 \\
7 & $75 \%$ & $4 \mathrm{~mm} / \mathrm{s}$ & $5 \mathrm{~mm}$ & 0.6171 & 0.3829 & 0.5663 \\
8 & $75 \%$ & $5 \mathrm{~mm} / \mathrm{s}$ & $3 \mathrm{~mm}$ & 0.2589 & 0.7411 & 0.4029 \\
9 & $75 \%$ & $6 \mathrm{~mm} / \mathrm{s}$ & $4 \mathrm{~mm}$ & 0.4072 & 0.5928 & 0.4575 \\
\hline
\end{tabular}

Table 12. Grey Relational Value of carbon emission

\begin{tabular}{|c|c|c|c|c|c|c|}
\hline \multicolumn{7}{|c|}{ Gray Relational Value of Carbon Emission Response } \\
\hline \multirow{2}{*}{ No } & \multicolumn{3}{|c|}{ Combination of Parameter } & \multirow{2}{*}{ Normalization } & \multirow{2}{*}{ Deviation } & \multirow{2}{*}{ GRC } \\
\hline & Laser Power & Cutting Speed & Nozzle Distance & & & \\
\hline 1 & $55 \%$ & $4 \mathrm{~mm} / \mathrm{s}$ & $3 \mathrm{~mm}$ & 0.3547 & 0.6453 & 0.4366 \\
\hline 2 & $55 \%$ & $5 \mathrm{~mm} / \mathrm{s}$ & $4 \mathrm{~mm}$ & 0.1298 & 0.8702 & 0.3649 \\
\hline 3 & $55 \%$ & $6 \mathrm{~mm} / \mathrm{s}$ & $5 \mathrm{~mm}$ & 0.0000 & 1.0000 & 0.3333 \\
\hline 4 & $65 \%$ & $4 \mathrm{~mm} / \mathrm{s}$ & $4 \mathrm{~mm}$ & 1.0000 & 0.0000 & 1.0000 \\
\hline 5 & $65 \%$ & $5 \mathrm{~mm} / \mathrm{s}$ & $5 \mathrm{~mm}$ & 0.8645 & 0.1355 & 0.7868 \\
\hline 6 & $65 \%$ & $6 \mathrm{~mm} / \mathrm{s}$ & $3 \mathrm{~mm}$ & 0.5642 & 0.4358 & 0.5343 \\
\hline 7 & $75 \%$ & $4 \mathrm{~mm} / \mathrm{s}$ & $5 \mathrm{~mm}$ & 0.8981 & 0.1019 & 0.8306 \\
\hline 8 & $75 \%$ & $5 \mathrm{~mm} / \mathrm{s}$ & $3 \mathrm{~mm}$ & 0.7876 & 0.2124 & 0.7018 \\
\hline 9 & $75 \%$ & $6 \mathrm{~mm} / \mathrm{s}$ & $4 \mathrm{~mm}$ & 0.6554 & 0.3446 & 0.5920 \\
\hline
\end{tabular}

Based on the GRC in Tables 9-12, the Grey Relational Grade (GRG) of each treatment is then calculated as shown in Table 13. The table also shows the ranking of each treatment according to the GRG. In this research, treatment number 4 is considered as the best one with the factor combinations of parameters laser power, cutting speed, and nozzle distance at Level 2, Level 1, and Level 2 respectively. 
Table 13. Grey Relational Grade value

\begin{tabular}{|c|c|c|c|c|c|c|}
\hline \multirow[b]{2}{*}{ No } & \multicolumn{4}{|c|}{ GRC } & \multirow[b]{2}{*}{ GRG } & \multirow[b]{2}{*}{ Ranking } \\
\hline & $\begin{array}{l}\text { Processing } \\
\text { Time }\end{array}$ & $\begin{array}{l}\text { Dimensional } \\
\text { Accuracy }\end{array}$ & $\begin{array}{c}\text { Surface } \\
\text { Roughness }\end{array}$ & $\begin{array}{l}\text { Carbon } \\
\text { Emission }\end{array}$ & & \\
\hline 1 & 1.0000 & 0.4317 & 0.3333 & 0.4366 & 0.5504 & 6 \\
\hline 2 & 0.4828 & 0.9107 & 0.4398 & 0.3649 & 0.5496 & 7 \\
\hline 3 & 0.3333 & 0.6509 & 1.0000 & 0.3333 & 0.5794 & 4 \\
\hline 4 & 1.0000 & 0.4607 & 0.4684 & 1.0000 & 0.7323 & 1 \\
\hline 5 & 0.4828 & 0.5191 & 0.5044 & 0.7868 & 0.5733 & 5 \\
\hline 6 & 0.3333 & 0.7195 & 0.4931 & 0.5343 & 0.5201 & 9 \\
\hline 7 & 1.0000 & 0.3333 & 0.5663 & 0.8306 & 0.6826 & 2 \\
\hline 8 & 0.4828 & 0.4941 & 0.4029 & 0.7018 & 0.5204 & 8 \\
\hline 9 & 0.3333 & 1.0000 & 0.4575 & 0.5920 & 0.5957 & 3 \\
\hline
\end{tabular}

\subsection{Response Surface Methodology}

Response surface methodology is a method used to determine the mathematical model that represents the result of an experiment. We tested the model against two equations, namely linear and quadratic for each response. Table 4 listed the results of such using Minitab 2017 software.

Table 14. Summary of ANOVA for each response

\begin{tabular}{|c|c|c|c|c|c|c|c|c|c|}
\hline \multicolumn{10}{|c|}{ ANOVA for Each Response } \\
\hline \multirow[b]{2}{*}{ Source } & \multirow[b]{2}{*}{$\mathrm{DF}$} & \multicolumn{2}{|c|}{ Processing Time } & \multicolumn{2}{|c|}{$\begin{array}{c}\text { Dimensional } \\
\text { Accuracy }\end{array}$} & \multicolumn{2}{|c|}{ Surface Roughness } & \multicolumn{2}{|c|}{ Carbon Emissions } \\
\hline & & Adj SS & P-Value & Adj SS & P-Value & Adj SS & P-Value & Adj SS & P-Value \\
\hline \multicolumn{10}{|l|}{ Model } \\
\hline Linear & 3 & 1300.50 & $0.000^{*}$ & 0.000009 & $0.000^{*}$ & 0.08910 & $0.001^{*}$ & 708.25 & $0.000^{*}$ \\
\hline Laser Power & 1 & 0.00 & 1.000 & 0.000001 & 0.088 & 0.00383 & 0.319 & 527.81 & $0.000^{*}$ \\
\hline Cutting Speed & 1 & 1300.50 & $0.000^{*}$ & 0.000008 & $0.000^{*}$ & 0.02017 & $0.029^{*}$ & 177.26 & $0.001^{*}$ \\
\hline Nozzle Distance & 1 & 0.00 & 1.000 & 0.000000 & 0.235 & 0.06510 & $0.000^{*}$ & 3.18 & 0.614 \\
\hline Square & 3 & 13.50 & $0.000^{*}$ & 0.000003 & $0.012^{*}$ & 0.15078 & 0.280 & 218.56 & $0.004^{*}$ \\
\hline Laser Power ${ }^{2}$ & 1 & 0.00 & 1.000 & 0.000000 & 1.000 & 0.00065 & 0.678 & 217.05 & $0.000^{*}$ \\
\hline Cutting Speed ${ }^{2}$ & 1 & 13.50 & $0.000^{*}$ & 0.000000 & 0.218 & 0.00825 & 0.149 & 0.38 & 0.861 \\
\hline Nozzle Distance $^{2}$ & 1 & 0.00 & 1.000 & 0.000003 & $0.002^{*}$ & 0.00618 & 0.209 & 1.14 & 0.762 \\
\hline Error & 20 & 0.00 & & 0.000005 & & 0.07319 & & 242.43 & \\
\hline Lack-of-Fit & 2 & 0.00 & 1.000 & 0.000000 & 0.737 & 0.02555 & $0.021^{*}$ & 13.79 & 0.590 \\
\hline Pure Error & 18 & 0.00 & & 0.000004 & & 0.04764 & & 228.63 & \\
\hline Total & 26 & 1314.00 & & 0.000017 & & 0.17736 & & 1169.24 & \\
\hline
\end{tabular}

Based on Table 14, both linear and quadratic models have significant affected in making linear and quadratic equations determined by the value of the P-Value less than 0.05 , so there are linear and quadratic equations. For processing time, linear and quadratic equation using factor cutting speed. Response dimensional accuracy, linear equation using factor laser power, cutting speed, and nozzle distance and quadratic equation using factor nozzle distance. Response 
surface roughness, linear equation using factor laser power, cutting speed, and nozzle distance and quadratic equation using factor cutting speed. Response carbon emissions, linear equation using factor laser power, cutting speed, and nozzle distance and quadratic equation using factor laser power.

TABLE 15 Fit Summary for Linear and Quadratic Equations

\begin{tabular}{lcccc}
\hline \multicolumn{5}{c}{ Model Summary } \\
\hline Response & Standard Deviaton & $\mathrm{R}^{2}$ & Adjusted R & Predicted R \\
\hline Processing Time & 0 & $100.00 \%$ & $100.00 \%$ & $100.00 \%$ \\
Dimensional Accuracy & 0.0004772 & $70.91 \%$ & $65.62 \%$ & $57.31 \%$ \\
Surface Roughness & 0.0603083 & $54.89 \%$ & $46.68 \%$ & $32.25 \%$ \\
Carbon Emissions & 3.32993 & $79.14 \%$ & $75.34 \%$ & $68.13 \%$ \\
\hline
\end{tabular}

The output for fit summary results in Table 15 clearly shows that for each response from the Minitab 2017 software, the second order polynomial gives relatively good results. By dropping the insignificant factor in each response, then the model for each response can be expressed as the following:

$Y_{1}=119-23.50 x_{2}+1.50 x_{2}^{2}$

$Y_{2}=0.98502-0.00204 x_{1}+0.000676 x_{2}+0.00542 x_{3}-0.000694 x_{3}^{2}$

$Y_{3}=0.783-0.146 x_{1}+0.337 x_{2}+0.060 x_{3}-0.037 x_{2}^{2}$

$Y_{4}=-227.80+836 x_{1}-3.138 x_{2}+0.420 x_{3}-601 x_{1}^{2}$

\subsection{Multi-Objective Optimization}

Multi-objective optimization is a decision making method related to mathematical optimization problems involving more than one objective function. The optimization of the model is done using normalization approach. The normalized value of all the responses is shown in Equations 10-13., while the set of constraints are shown in Equations 14-16.Before normalizing the data, it is necessary to find the minimum and maximum and values of each response using Equations 5-8. The maximum and minimum values of each response as the results of the optimization are shown in Table 16. Using Equation 9 as the objective function and Equations 14-16 as the constraints, the optimization resulted in the optimal laser power of $75 \%$, cutting speed of 5.9 $\mathrm{mm} / \mathrm{s}$, and nozzle distance of $3 \mathrm{~mm}$.

TABLE 16 Max Value and Min Value of Each Response

\begin{tabular}{lcc}
\hline \multicolumn{1}{c}{ Response } & Maximum Value & Minimum Value \\
\hline Processing Time & 49 & 32 \\
Dimensional Accuracy & $99.85 \%$ & $99.59 \%$ \\
Surface Roughness & 0.3168 & 0.08851 \\
Carbon Emission & 52.47 & 43.57 \\
\hline
\end{tabular}

$\operatorname{Min} Z=f_{1}(x)+f_{2}(x)+f_{3}(x)+f_{4}(x)$ 
1. Minimize Processing Time

$$
f_{1}(x)=\frac{\left(119-23.50 x_{2}+1.5 x_{2}{ }^{2}\right)-32}{17}
$$

2. Maximize Dimensional Accuracy

$$
f_{2}(x)=\frac{\left(0.98502-0.00204 x_{1}+0.000676 x+0.00542 x-0.000694 x^{2}\right)-0.9959}{0.002592277}
$$

3. Minimize Surface Roughness

$$
f_{3}(x)=\frac{\left(0.783-0.146 x_{1}-0.337 x_{2}+0.0601 x_{3}-0.0371 x_{2}^{2}\right)-0.08851}{0.228289757}
$$

4. Minimize Carbon Emission

$$
f_{4}(x)=\frac{\left(-227.8+836 x_{1}-3.138 x_{2}+0.420 x_{3}-601 x_{1}{ }^{2}\right)-43.5695}{8.900629784}
$$

s.t

1. Laser Power

$$
55 \% \leq x_{1} \leq 75 \%
$$

2. Cutting Speed

$$
4 \leq x_{2} \leq 6
$$

3. Nozzle Distance

$3 \leq x_{3} \leq 5$

\section{Conclusions}

In this research, we conducted research to determine the optimal process parameters setting in the acrylic cutting process using a $\mathrm{CNC} \mathrm{CO}_{2}$ Laser Cutting machine. The experiment was conducted using multi-response Taguchi method involving four responses, namely processing time, dimensional accuracy, surface roughness, and carbon emissions. The Taguchi method is done to determine the SNR for each response. The GRA method is used to determine simultaneously the optimal process parameters setting for each factor in the experiment. The Response Surface Methodology (RSM) was applied to determine the mathematical model based on the results of the experiment to allow the multi-objective optimization and determine the exact value of optimal process parameters which simultaneously compromise the responses. Based on the results of the experiment, the optimal process parameters are $65 \%$ of the laser power, $4 \mathrm{~mm} / \mathrm{s}$ of the cutting speed, and $4 \mathrm{~mm}$ of nozzle distance. Whereas from the results of RSM method, the optimal process parameters are $75 \%$ of laser power, $5.9 \mathrm{~mm} / \mathrm{s}$ of cutting speed, and $3 \mathrm{~mm}$ of nozzle distance.

Author Contributions Conceptualization: CNR, EMO, EP; Methodology: CNR, EP; Investigation: EMO, CNR; Resources: CNR, EMO, EP; Data curation: EMO; Writingoriginal draft preparation: EMO, CNR, EP; Visualization: EMO; Supervision: CNR,EP; Funding acquisition: CNR, EP.

Funding This work was funded by Lembaga Penelitian dan Pengabdian Masyarakat of Universitas Sebelas Maret under Mandatory Research Scheme with contract number 260/UN27.22/HK.07.00/2021 
Data Availability All the data are available in the manuscript.

Conflict of Interest The authors declare that no conflict of interest exists in this research.

\section{References}

Acherjee, B. \& dkk. (2014). Grey relational analysis based optimization of underwater Nd:YAG laser micro-channeling on PMMA. Procedia Engineering 97, pp. 1406-1415 Al-Refaie A., Wu, T-H., dan Li, M-H. (2010). An Effective Approach for Solving the Multiresponse Problem in Taguchi Method. Jordan Journal of Mechanical and Industrial Engineering 4(2), pp. 314-323

Armansyah, M. M., Purwanti, E. P., \& Karuniawan, B. W. (2016). Optimasi Parameter Proses Pemotongan Acrylic terhadap Kekasaran Permukaan Menggunakan Laser Cutting dengan Metode Response Surface. Retrieved from journal.ppns.ac.id on September 4, 2021.

Bambang, A \& Arnanta, I. W. (2015). Teknologi Polimer. Udayana: Universitas Udayana.

Chen, X. et al. (2016). Using orthogonal experimental method optimizing surface quality of CO2 laser cutting process for PMMA microchannels. International Journal Advanced Manufacture Technology.

Ding, H., Wang, Z., \& Guo, Y. (2020). Multi-objective optimization of fiber laser cutting based on generalized regression neural network and non-dominated sorting genetic algorithm. Infrared Physics and Technology, 108.

El-Hofy, H. (2013). Fundamentals of Machining Processes: Conventional and Nonconventional Processes, Second Edition. USA: CRC Press.

Eltawahni, H., Olabi, A. G., and Benyounis, K. Y. (2019). $\mathrm{CO}_{2}$ Laser Cutting Process of PMMA, Reference Module in Materials Science and Materials Engineering, Elsevier.

Groover, M.P. (2012). Fundamentals of Modern Manufacturing: Material, Processes, and Systems, fifth edition. Hoboken: Wiley.

Haddadi, E. et al. (2019). Experimental and parametric evaluation of cut quality characteristics in $\mathrm{CO} 2$ laser cutting of polystyrene. International Journal for Light and Electron Optics, 184:103-114

Khamar, P. \& Prakash, S.(2020). Investigation of dimensional accuracy in CO2 laser cuntting of PMMA. School of Engineering and Apllied Science. India.

Kellens, K., Rodrigues, G.C., Dewulf, W., \& Duflou, J. R.(2014). Energy and Resource Efficiency of Laser Cutting Processes. Department of Mechanical Engineering. Belgia. 
Kim, M. J., \& Majumdar, P. (2007). Computational Model For High-Energy Laser-Cutting Process. International Journal of Computation and Methodology, 27(6), 717-733. Doi:10.1080/10407789508913728.

Kuo, Y., Yang, T., \& Huang, G.-W. (2008). The use of a grey-based Taguchi method for optimizing multi-response simulation problems. Engineering Optimization, Vol. 40 (6), 517-528. DOI:10.1016/j.cie.2007.12.002

Lopez, A., Assuncao, E., Pires, I., \& Quintino, L. (2017). Secondary emissions during fiber laser cutting of nuclear material. Nuclear Engineering and Design, 315, 69-76.

Marler, R. T., and Arora, J. S. (2004). Survey of Multi-Objective Optimization Methods for Engineering, Structural and Mulidisciplinary Optimization 26, pp. 369-395.

Mathivanan, S., Ji, H. and Simpson, R.J. (2010) Exosomes: Extracellular Organelles Important in Intercellular Communication. Journal of Proteomics, 73, 1907-1920.

Moradi, M., Moghadam, M. K., Shamsborhan, M., Beiranvand, Z. M., Rasouli, A., Vahdati, M., Bakhtiari, A., and Bodaghi, M. (2021), Optik 225, 164932.

Naresh and Khatak, P. (2021). Laser Cutting Technique: A Literature Review, Materials Today: Proceedings, the $3^{\text {rd }}$ International Conference on Contemporary Advances in Mechanical Engineering, 27-28 August 2021, Punjab, India.

Rakasita R., Karuniawan B. W., \& Anda Iviana Juniani. (2016). Optimasi Parameter Mesin Laser Cutting Terhadap Kekasaran Dan Laju Pemotongan Pada Sus 3161 Menggunakan Taguchi Grey Relational Analysis Method. Surabaya: Teknik Permesinan Kapal Politeknik Perkapalan Negeri Surabaya.

Shaker, K., M. Umair, M. Maqsood, Y. Nawab, S. Ahmad, A. Rasheed, . . .. A. Basit. 2015 A Statistical Approach for Obtaining the Controlled Woven Fabric Width. Autex Research Journal, Vol. 15 (4): 275-279. DOI: 10.1515/aut-2015-0008

Widarto et al, (2008). Teknik Pemesinan. Jakarta: Direktorat Jendral Manajemen Pendidikan Dasar dan Menengah. 